\title{
Circulating Plasma Cell
}

National Cancer Institute

\section{Source}

National Cancer Institute. Circulating Plasma Cell. NCI Thesaurus. Code C114278.

A plasma cell myeloma-derived cell found in the peripheral blood. 